\title{
Should conservationists continue to dodge the issue of tax dodging?
}

\author{
Jonathan H. Hanson and David MCNaIR
}

Tax is critical to the effective functioning of the majority of states, providing resources to fund public services such as schools, hospitals and infrastructure. In the face of recent austerity programmes tax evasion and avoidance have received significant political attention, both in the UK and further afield. This is not least because of the burdens borne by taxpayers in bailing out banks and other institutions following the 2008 financial crisis, and associated public anger at the tax practices of some large firms and high net-worth individuals. Should conservationists consider the issues of tax evasion and avoidance (popularly referred to as tax dodging) as relevant to the conservation of biodiversity? We argue that, although empirical analyses are needed to explicate and clarify potential relationships between these issues, tax dodging may hold particular relevance for biodiversity loss and for conservation.

Although the levels and nature of taxation are political decisions, there is a growing consensus that the ability of a country to tax its citizens and spend revenues is a proxy for stable and well-governed states-critical for the protection of stable social situations and the protection of the environment. Cobham (2005) outlined four functions of taxation: (1) revenue, to finance social and infrastructure spending; (2) representation, to strengthen the development of effective institutions and their responsiveness to citizens; (3) redistribution, to mobilize and allocate resources to address inequality; and (4) re-pricing, to increase the costs of harmful consumption and subsidize beneficial products and services.

Recent debates on human development have increasingly focused on the harm done by those that seek to undermine effective taxation through illegal tax evasion, aggressive tax avoidance, and the exploitation of loopholes between tax jurisdictions. Analysis by Global Financial Integrity of these illicit financial flows from developing countries suggests that nominal illicit outflows amounted to USD 946.7 billion in 2011, up $13.7 \%$ from USD 832.4 billion in 2010 (GFI, 2013) Controlled for inflation, illicit outflows from developing countries increased in real terms by c. $10.2 \%$ per annum over the past decade. From a human development perspective, this has grave impacts. In 2008 Christian Aid estimated

Jonathan H. Hanson (Corresponding author) Department of Geography, University of Cambridge, Cambridge, CB2 3EN, UK. E-mail jh847@cam.ac.uk

DAVID MCNAIR London, UK that the money estimated to have been lost to tax dodging, if invested according to current spending patterns, could save the lives of 350,000 children each year (Christian Aid, 2008).

From the perspective of biodiversity conservation, tax is directly relevant as an important funding source. Tax provides financial resources for much of the apparatus of conservation at national and international levels (Balmford \& Whitten, 2003). In addition, many conservation NGOs are financially dependent on tax-funded grants as well as income from individual donors. Also of relevance are the funding shortfalls faced by conservation that could be met, in part, by increased public investment were biodiversity of greater political importance. To the best of our knowledge no comprehensive overviews of the breakdown of global conservation funding into public and private sources are available.

What are available, however, are a limited number of cost projections for various components of conservation worldwide, as well as the funding shortfalls needed to implement them fully. The financial cost of a comprehensive global conservation programme, for example, was estimated by James et al. (1999) to be USD 300 billion, the vast majority of which was for the conservation of biodiversity in landscapes outside protected areas as a result of loss of opportunity costs associated with particular industries or activities. They also calculated that the funding shortfall for managing the existing protected area network at the turn of the century was c. USD 2.3 billion per year, a significant amount given the USD 6 billion spent annually on management costs.

Studies since then have looked at the costs and funding shortfalls of protected areas in particular regions of the world. They found similar results. Balmford \& Whitten (2003) estimated the gap in funding for protected area management in tropical regions to be USD 1.5 billion annually, and Bruner et al. (2004) found it to be USD 1-1.7 billion per year in developing countries. These funding shortfalls exceeded the amounts being spent on protected area management in both cases: USD 0.75 billion and USD 0.6 billion in tropical and developing countries, respectively.

If tax is therefore important for contributing to existing biodiversity conservation efforts, such as protected area establishment and management, the lack of or leakage of tax revenue could undermine the ability of a nation state to fund the conservation of its biodiversity, and may be a factor in the funding shortfalls outlined above. The situation may be particularly acute in the Global South, with its often weak 
and underfunded conservation and tax collection institutions (Smith \& Walpole, 2005; Christian Aid, 2008).

The second area where tax dodging may be of particular relevance to conservation is governance. Poorly governed and unstable nation states that are losing significant tax revenues are likely to be less effective at biodiversity conservation and at providing the social context for it to occur. Given the absence, as far as we are aware, of any empirical research that links tax dodging to biodiversity loss and conservation, the example of corruption may serve to illustrate the potential correlations.

The factors that facilitate tax dodging-financial secrecy in tax havens and an absence of corporate transparencyalso facilitate corruption. Smith et al. (2003), using Transparency International's Corruption Perception Index as a barometer of corruption, found that better governance scores were correlated with increasing elephant and black rhino populations across the relevant African states. Smith \& Walpole (2005) suggested that corruption could affect conservation by directly reducing the effectiveness of conservation programmes and by incentivizing the overexploitation of resources. In responding to Smith \& Walpole, Ferraro (2005) and Katzner (2005) both noted the complexity of any linkages between corruption and conservation and that these could be both positive and negative for conservation. Katzner (2005), for instance, identified a significant negative correlation between governance scores from Transparency International's Corruption Perception Index and European farmland bird populations from 1970 to 1990.

The connections between corruption and conservation remain an under-researched aspect of conservation scholarship. Yet, given the absence of any other analyses, the extant studies may be the best proxy for attempting to understand the possible connections between tax dodging, governance and biodiversity conservation. Are, for example, the effects on conservation of money leaking from an economy as a result of corruption similar to the effects of money leaking because of tax evasion and avoidance? Are farmland bird, elephant and black rhino population trends positively or negatively correlated with levels of tax dodging?

There are, however, a number of caveats in assuming that conservation outcomes will automatically improve if tax dodging is reduced and tax revenues are increased. Firstly, there is the issue of power dynamics between government departments. Departments responsible for biodiversity conservation often have less political power than those responsible for health, infrastructure, defence and the like (Wells, 1998). More tax retained may therefore not mean more revenue being allocated to conservation budgets without a concurrent increase in the political attention paid to biodiversity conservation.

Secondly, appropriate and effective taxation is only one factor among several associated with good governance
(Cobham, 2005). Even with more revenue retained from reducing tax evasion and avoidance, other issues, such as a lack of transparency and accountability, would need to be addressed simultaneously to ensure the effectiveness of conservation. Thirdly, there is the link between tax-funded development and biodiversity loss (Adams, 2013). Increased government spending on development, funded by an increased tax-take, may provide greater resources for conservation but also contribute to increased biodiversity loss without the relevant safeguards, such as mainstreaming biodiversity issues within wider socio-economic policies.

Empirical analyses are needed to explore and quantify the potential relationships between biodiversity loss, conservation and tax dodging. The solution to this dearth of information is also part of a broader challenge for conservation, namely to understand and address biodiversity loss more fully in relation to broader societal issues such as the world economy and global governance (Adams, 2013). Conservationists cannot afford to dodge these issues any longer.

\section{References}

Adams, W.M. (2013) Conservation in the Anthropocene: biodiversity, poverty and sustainability. In Biodiversity Conservation and Poverty Alleviation: Exploring the Evidence for a Link (eds D. Roe, J. Elliott, C. Sandbrook \& M. Walpole), pp. 304-315. Wiley-Blackwell, Chichester, UK.

Balmford, A. \& Whitten, T. (2003) Who should pay for tropical conservation, and how could the costs be met? Oryx, 37, $238-250$.

Bruner, A.G., Gullison, R.E. \& Balmford, A. (2004) Financial costs and shortfalls of managing and expanding protected-area systems in developing countries. BioScience, 54, 1119-1126.

Christian Aid (2008) Death and Taxes: The True Toll of Tax Dodging. Http://www.christianaid.org.uk/images/deathandtaxes.pdf [accessed 17 April 2014]

Coвн ам, A. (2005) Taxation Policy and Development. Oxford Council on Good Governance Economy Analysis No. 2. Http://www. taxjustice.net/cms/upload/pdf/OCGG___Alex_Cobham__Taxation_Policy_and_Development.pdf [accessed 8 January 2014].

Ferraro, P. (2005) Corruption and conservation: the need for empirical analyses. A response to Smith \& Walpole. Oryx, 39, 257-259.

GFI (Global Financial Integrity) (2013) Illicit Financial Flows from Developing Countries: 2002-2011. Http://iff.gfintegrity.org/ iff2013/2013report.html [accessed 17 April 2014].

James, A.N, Gaston, J.K. \& Balmford, A. (1999) Balancing the world's accounts. Nature, 41, 323-324.

KatZner, T.E. (2005) Corruption-a double-edged sword for conservation? A response to Smith \& Walpole. Oryx, 39, 260-262.

Smith, R.J., Muir, R.D.J., Walpole, M.J., Balmford, A. \& Leader-Williams, N. (2003) Governance and the loss of biodiversity. Nature, 426, 67-70.

Smith, R.J. \& Walpole, M.J. (2005) Should conservationists pay more attention to corruption? Oryx, 39, 251-256.

WelLs, M.P. (1998) Institutions and incentives for biodiversity conservation. Biodiversity and Conservation, 7, 815-835. 